J. Linguistics 59 (2023), 121-148. C The Author(s), 2022. Published by Cambridge University Press. This is an Open Access article, distributed under the terms of the Creative Commons Attribution licence (https://creativecommons.org/licenses/by/4.0/), which permits unrestricted re-use, distribution, and reproduction in any medium, provided the original work is properly cited.

doi:10.1017/S0022226722000020

\title{
Noun class agreement in Kafire (Senufo): A Lexical-Functional Grammar account ${ }^{1}$
}

\author{
TATIANA NIKITINA \\ CNRS-LACITO \\ SONGFOLO LACINA SILUÉ \\ INALCO
}

(Received 4 October 2020; revised 14 January 2022)

\begin{abstract}
A major challenge presented by noun class systems of Senufo languages is the non-trivial interaction between the agreement features of the noun phrase and the noun class specification on the head noun. In Kafire (Senufo, Côte d'Ivoire), demonstratives normally agree with the head noun independent of whether or not the head noun is modified by adjectives. Some adjectives, however, are exceptions to the general rule: in their presence the demonstrative appears in Class 2 or 3 (depending on the adjective), and fails to agree with the head noun. We present an account of the exceptional behavior of such adjectives within the framework of Lexical-Functional Grammar. We show that agreement in Kafire is a heterogeneous phenomenon that is best viewed as transitional between a system of semantically motivated agreement and a system of noun classes that is no longer dependent on meaning. Vestiges of the old system have been preserved in a variety of phenomena that have to be addressed individually using different kinds of formal tools provided by the framework. The variety of formal devices required to describe the functioning of the agreement system reflects the complex diachrony and the cross-modal (lexico-syntactic) synchronic nature of agreement phenomena.
\end{abstract}

Keywords: noun class, agreement, Senufo, Lexical-Functional Grammar, determiners

\section{INTRODUCTION}

A central component of any syntactic framework is theory of agreement, yet studies comparing the potential of different formal approaches to agreement are still hard to come by (for recent examples, see Bond et al. 2016, Haug \& Nikitina 2016).

[1] This project has received funding from the European Research Council (ERC) under the European Union's Horizon 2020 Research and Innovation Programme (grant agreement No 758232). We are grateful to the audience of the 25th International Lexical-Functional Grammar Conference, the editors, and the anonymous reviewers for valuable feedback on earlier versions of this article. We also thank Silue Koronan, Silué Yardjouma and Soro Karna for their help and availability for consultations on Kafire, in spite of the pandemic. 
Similarly underdeveloped is the typology of the ways diachronic processes are reflected in the synchronic functioning of agreement systems and of the ways different agreement mechanisms co-exist and compete in a single language. This study aims to contribute to the study of agreement phenomena across languages through an investigation of noun class agreement in Kafire, a Senufo language spoken in Côte d'Ivoire. Although simple on the surface, the noun class system of Kafire presents a number of challenges, and a variety of different formal tools have to be used to account for it.

One of the major challenges presented by noun class systems of Senufo languages is the non-trivial interaction between the agreement features of the noun phrase and the noun class specification on the head noun. In Kafire, for example, demonstratives normally agree with the head noun, such as $p \bar{\Sigma}$ ' $\operatorname{dog}$ ', of Class 1 , in (1) or túbéré 'shoe', of Class 2, in (2). The agreement is independent of the determiner's position: the same demonstrative can precede or follow the noun in (1)-(2).
(1) (a) wè $\mathrm{p} \bar{\sim}=\mathrm{w}$
this.CL1 dog $=$ CL1.DEF
(b) $\mathrm{p} \bar{\sim}=\mathrm{w}$ wè $\operatorname{dog}=$ CL1.DEF this.CL1 'this dog'
(2) (a) gè túbéré=g
(b) túbéré=g gè shoe $=$ CL2.DEF this.CL2 'this shoe'
this.CL2 shoe $=$ CL2.DEF

The agreement of demonstratives with the head noun is normally not affected by the presence of adjectives. In (3) and (4) the same nouns $p \bar{\sim}$ 'dog' and túbér $r \varepsilon$ 'shoe' are modified by an adjective, and that does not have an effect on the demonstrative (the same demonstratives are used as in the unmodified examples in (1)-(2)).

(3) (a) wè $\quad$ D̃ wó $=\mathrm{w}$
this.CL1 dog black=CL1.DEF
(b) $\mathrm{p} \bar{\sim}$ wó=w wè dog black $=$ CL1.DEF this.CL1 'this black dog'
(4) (a) gè túbéré $\int \varepsilon_{\alpha}^{\prime}-w \bar{o}=\mathrm{g}$ this.CL2 shoe two-ADJVZ=CL2.DEF
(b) túbćŕ́ $\int_{\tilde{\varepsilon}}^{-}-\mathrm{wo}=\mathrm{g} \quad$ gè shoe two-ADJVZ=CL2.DEF this.CL2 'this second shoe'

Some adjectives, however, are exceptions to the general rule (we are aware of six such exceptional adjectives in Kafire). In the presence of an exceptional adjective, the demonstrative appears in Class 2 (in the case of kpó 'big', fálá 'lazy', kálá 
'clownish') or in Class 3 (in the case of $p \bar{l}$ 'little', $k p \bar{e} l \bar{e}$ 'short', prō 'idiot'), failing to agree with the head noun. In (5), for example, the demonstratives are in Class 2 and Class 3 because of the adjectives, even though the head noun $p \bar{\sim}$ ' $d o g$ ' is normally Class 1 (as shown above).
(a) jè
p⿳亠丷厂 gbóló $=\mathrm{j}$
this.CL2.PL dog big=CL2.DEF.PL 'these big dogs'
(b) lè $\quad \mathrm{p} \bar{\sim} \quad \mathrm{b} \overline{\mathrm{i}}=1$
this.CL3 dog little=CL3.DEF
'this little dog'

Another non-trivial property of the noun class system of Kafire (and apparently Senufo languages more generally, cf. Traoré 2020 for parallel data from Tagbana) is the way noun class markers can contribute their own meaning. Some of the noun class markers can combine with a noun that normally does not belong to that class, resulting in a change in the noun's denotational meaning.

In this study, we explore these puzzling phenomena and suggest a formal account of both noun class agreement with adjectives and semantically motivated use of noun class markers in Kafire. Our formal account is grounded in the lexicalist constraint-based framework of Lexical-Functional Grammar (see Kaplan \& Bresnan 1982 for an early formal outline of general principles; Dalrymple et al. 2019 for a recent comprehensive overview; Falk 2001, Bresnan et al. 2015, Börjars et al. 2019 for student-level introductions). We use Lexical-Functional Grammar as our theoretical framework because of its flexible lexicalist architecture: as we explain in the paper, it allows us to treat different kinds of challenging phenomena at different levels of structure. The variety of formal tools required to describe the functioning of the agreement system reflects the cross-modal (lexico-syntactic) nature of agreement phenomena in Kafire as well as their complex diachrony.

The rest of the paper is organized as follows. We first present, in a theory-neutral way, the basics of the noun phrase structure of Kafire and lay out the essentials of our account (Sections 2-3). Some of the aspects of our account are in stark contrast with the widely accepted traditional views on Senufo class markers (most importantly, we argue that they are best analyzed as clitics rather than suffixes). We then present our formal solution to the problem of class-assigning adjectives and give evidence for the partially semantic nature of the agreement system (Section 4). We end with a brief discussion of our account's implications (Section 5).

\section{The noun Class system of Kafire}

\subsection{Background information}

Kafire is a Senufo language from the Central Senari group, spoken in three subprefectures (Sirasso, Nafoun and Kanoroba) in the department of Korhogo in Northern Côte d'Ivoire. It is as yet undescribed, apart from the lexical and 
phonological description in Silué 2017. This study is part of an ongoing documentation project that relies on an analysis of a corpus of traditional narratives (Silué In prep.b), complemented with elicitation sessions with native speakers. Our examples are either constructed in consultation with native speakers during elicitation sessions or extracted from the narrative corpus under development (in which case reference is given to the relevant story in the corpus and the segment in the story).

This study is the first formal description of agreement phenomena in Kafire. Silué 2017 gives a brief sketch of the noun class system but does not describe the phenomena that we discuss here. Descriptions of noun class systems can be found in grammars of other Senufo languages (Carlson 1994, Dombrowsky-Hahn 2015), as well as in formally oriented studies by Baron 2016 (for Nafara) and Traoré \& Féry 2018, Traoré 2020 (for Tagbana). Yéo 2012 is a comparative study of data from several languages.

Senufo languages are traditionally classified as a subgroup within the Gur family; more recently, they have been treated as a family related to Gur within the VoltaCongo group (Hammarström et al. 2021). Noun class systems of Gur languages have received considerable attention (Nicole 1999, Miehe \& Winkelmann, eds. 2007, inter alia), but the extent to which they function in the same way as in Senufo languages remains unknown.

\subsection{Elements that agree in noun class}

Each noun is associated in Kafire with one of five noun classes (we leave aside for the moment cases of polysemy where the same noun is associated with more than one class depending on its meaning; we return to them later). The noun class is manifested in the choice of an obligatory noun class marker, in the form of the demonstratives, as well as in the form of several types of pronouns.

Different series of noun class markers are used in definite and indefinite contexts, and three of the five classes have different markers in the singular and in the plural. Table 1 lists the indefinite noun class markers, arranged in a way consistent with their description for some of the related Senufo languages (Welmers 1950, Carlson 1994, Baron 2016). Our arrangement differs from the one adopted in Miehe \& Winkelmann, eds. (2007) for Gur and those in Traoré \& Féry 2018 and Traoré 2020 for Tagbana in that it does not treat the singular and the plural markers as separate classes. Definite noun class markers are listed in Table 2.

All class markers are monosyllabic and have a CV structure, except for the plural markers of Classes 1 and 3, which consist of two syllables and are of the shape CVCV. In the case of monosyllabic markers, the distinction between the indefinite and the definite marker depends on the nature of the marker's vowel. In the indefinite, the vowel can have different realizations depending on the last vowel of the stem. In the definite marker, the vowel is always realized as $-i$, and tends to be omitted at the end of the word. In the case of two-syllable markers (CVCV), both vowels are realized as $-e$, and the indefinite and the definite marker only differ in 


\begin{tabular}{|c|c|c|}
\hline & Singular & Plural \\
\hline Class 1 & $\begin{array}{l}\text { nà=wà 'man' } \\
\text { têfálá=wá 'farmer' }\end{array}$ & $\begin{array}{l}\text { nà=bélè 'men' } \\
\text { têfálá=bélè 'farmers' }\end{array}$ \\
\hline Class 2 & cí $=\mathbf{g e} \overline{\mathbf{e}}$ 'tree' & cí=jē 'trees' \\
\hline Class 3 & $\begin{array}{l}\text { kpá=?ā 'house' } \\
\text { č́=nغ̀ 'egg' }\end{array}$ & $\begin{array}{l}\text { kpá=jāa 'houses' } \\
\text { ḉ=gèlè 'eggs' }\end{array}$ \\
\hline Class 4 & \multirow{2}{*}{\multicolumn{2}{|c|}{ 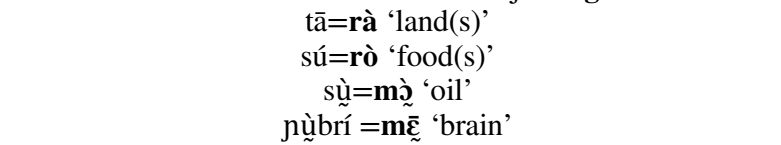 }} \\
\hline Class 5 & & \\
\hline
\end{tabular}

Table 1

Indefinite noun class markers of Kafire.

\begin{tabular}{|c|c|c|}
\hline & Singular & Plural \\
\hline Class 1 & $\begin{array}{l}\text { nà }=\mathbf{w}(\mathbf{i}) \text { 'the man' } \\
\text { têfálá }=\mathbf{w}(\mathbf{i}) \text { 'the farmer' }\end{array}$ & $\begin{array}{l}\text { nà=bèlè 'the men' } \\
\text { têfálá=bèlè 'the farmers' }\end{array}$ \\
\hline Class 2 & $\begin{array}{l}\text { cí=g(i) 'the tree' } \\
\text { kpá=g(i) 'the house' }\end{array}$ & $\begin{array}{l}\text { cí=j(i) 'the trees' } \\
\mathrm{kpá}=\mathbf{j}(\mathbf{i}) \text { 'the houses' }\end{array}$ \\
\hline Class 3 & $\begin{array}{l}\text { cé }=\mathbf{n}(\mathbf{i}) \text { 'the egg' } \\
\text { jédá=l(i) 'the foot sole' }\end{array}$ & $\begin{array}{l}\text { c⿱́丶́㇒́=gèlè 'the eggs' } \\
\text { jédá=gèlè 'the foot soles' }\end{array}$ \\
\hline Class 4 & \multirow{2}{*}{\multicolumn{2}{|c|}{ 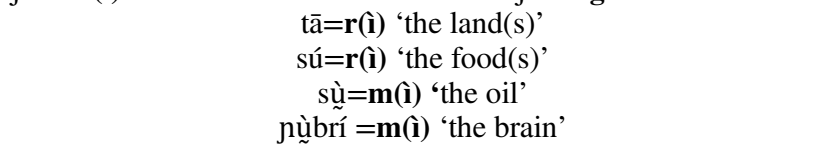 }} \\
\hline Class 5 & & \\
\hline
\end{tabular}

Table 2

Definite noun class markers of Kafire.

tone. We treat the definite markers as synchronically non-decomposable, even though they seem to derive, historically, from a combination of the indefinite (or the unmarked) class marker with the vowel $-i$.

Demonstratives are another element sensitive to class. There are two demonstratives in Kafire, a proximal and a distal one; both agree in class with the noun phrase. The forms of the demonstratives are listed in Tables 3-4; note that when the demonstrative follows the noun phrase, it must be preceded by a noun class marker.

Finally, several series of pronouns agree in noun class with their antecedent; Tables 5-6 list the corresponding forms of regular anaphoric and so-called emphatic anaphoric pronouns.

\subsection{The puzzling agreement with adjectives}

A crucial property of the agreement system that has already been introduced in Section 1 is the exceptional behavior of a number of adjectives which are associated 


\begin{tabular}{|c|c|c|}
\hline & Singular & Plural \\
\hline Class 1 & pì=w wè 'this child' & pì=bèlè bèlè 'these children' \\
\hline Class 2 & túbérć=g gè 'this shoe' & túbérć=j jè 'these shoes' \\
\hline Class 3 & $c \bar{\varepsilon}=1$ lè 'this calabash' & $c \bar{\varepsilon}=$ gèlè gèlè 'these calabashes' \\
\hline Class 4 & & tā $=$ r dè 'this land' \\
\hline Class 5 & & sù̀ =m bè 'this oil' \\
\hline
\end{tabular}

Table 3

The proximal demonstrative.

\begin{tabular}{|c|c|c|}
\hline & Singular & Plural \\
\hline Class 1 & pì=w wàa 'that child' & pì=bèlè bàlàá 'those children' \\
\hline Class 2 & túbćr'́́=g gàá 'that shoe' & túbérć=j jàá ‘those shoes’ \\
\hline Class 3 & $c \bar{\varepsilon}=1$ làá 'that calabash' & $c \bar{\varepsilon}=$ gèlè gàlàá 'those calabashes' \\
\hline Class 4 & \multirow{2}{*}{\multicolumn{2}{|c|}{$\begin{array}{l}\text { tā=r dàa 'that land' } \\
\text { sù=m bàá 'that oil' }\end{array}$}} \\
\hline Class 5 & & \\
\hline
\end{tabular}

Table 4

The distal demonstrative.

\begin{tabular}{llll}
\hline & Singular & & Plural \\
\hline Class 1 & wí & & bé \\
Class 2 & gí & & jí \\
Class 3 & lí & gé \\
Class 4 & & dí & \\
Class 5 & & bí & \\
\hline
\end{tabular}

Table 5

Anaphoric pronouns.

\begin{tabular}{llll}
\hline & Singular & & Plural \\
\hline Class 1 & wéè & & pélè \\
Class 2 & kéè & & jéé \\
Class 3 & léè & kélè \\
Class 4 & & téè & \\
Class 5 & & péè & \\
\hline
\end{tabular}

Table 6

Emphatic pronouns.

with their own inherent class (Class 2 for kpó 'big', fálá 'lazy', kálá 'clownish'; Class 3 for $p \bar{\imath}$ 'little', $k p \bar{e} l \bar{e}$ 'short', prō 'idiot'). These adjectives differ from regular adjectives in imposing their own class on the entire noun phrase: the noun phrase agrees with the adjective irrespective of the class of the head noun. This results in a seemingly paradoxical pattern: the class value contributed by the head noun is overruled, for the purposes of agreement, by the value of an adjectival modifier. 
The difference between the two types of adjectives is illustrated in (6)-(8). All adjectives follow their head noun and precede the noun class marker. Regular adjectives have no effect on the class of the noun phrase: the class marker in (6) is the one normally associated with the noun nà 'man'. The adjectives in (7)-(8), however, change the class of the entire noun phrase: the noun phrase becomes Class 2 or Class 3, depending on the adjective.
(6) (a) nà wó=wó
man black $=$ CL1
'a black man'
(b) nà wó=bélè
man black $=$ CL1.PL
'black men'
(7) (a) nà gbó =?̄̄
man $\quad$ big $=$ CL2
'a big man'
(b) nà̀ gbōló=jōo
man $\quad b i g=$ CL2.PL
'big men'
(8) (a) nà brō=lò
man idiot $=$ CL3
'an idiotic man'
(b) nà brō=gēlè
man idiot $=$ CL3.PL
'idiotic men'

The account we develop in the following sections addresses this split in the behavior of regular versus class-assigning adjectives. We suggest that both nouns and class-assigning adjectives are associated with class information, and both can pass on their class information to the noun phrase. The class information is encoded as part of the lexical entry of the noun or the adjective. Regular adjectives, however, are not associated with any class.

When a class-assigning adjective contributes class information that is not consistent with that of the head noun, the information contributed by the adjective takes precedence over that contributed by the noun, and the class associated with the adjective overrules the class associated with the noun. In our formal account (which we present in full in Section 4), we achieve this effect by making the class specification on the noun optional, so that it can be overruled by the class information contributed by a class-assigning adjective.

Making the class specification on nouns optional allows us to account for another non-trivial property of the noun class system of Kafire: the semantically motivated use of noun class markers. As we already mentioned, and as we discuss in detail below, some of the class markers can combine with nouns of a different class provided that they modify the noun's denotational meaning (Class 2 markers, for 
example, can attach to nouns of other classes in an augmentative reading). Such flexibility is allowed by the optionality of the class specification on nouns. Our account treats the relevant class markers as polyfunctional: in a neutral interpretation, they function as determiners that agree with the noun phrase, but they can also be used to alter the noun's meaning, irrespective of the noun's class.

Before we outline the details of our formal account, we discuss, in general terms, our treatment of the syntactic structure of the Kafire noun phrase, as it differs, as we already mentioned, from some of the previous accounts of noun class agreement in Senufo.

\section{The structure of the noun phrase in Kafire}

\subsection{Noun class markers are determiners, not suffixes}

We depart in our treatment from traditional accounts of Senufo noun class markers (Carlson 1994: 76; Manessy 1996a, 1996b; Yéo 2012; Traoré \& Féry 2018; Traoré 2020). Instead of analyzing them as nominal suffixes, we treat them, with Baron 2016, as clitics attaching to the last element of the noun phrase, which can be a noun or an adjective. Our evidence for this analysis comes from the way adjectives are integrated into the noun phrase.

Modifying adjectives always follow the nominal head. In this position, they are freely ordered, i.e. the ordering of adjectives is not determined strictly in terms of semantic notions such as color or size. The order of adjectival modifiers is defined instead by information-structure considerations: adjectives conveying new information and adjectives that are in focus are placed before adjectives conveying discourse-old information. Crucially, when the noun is modified by more than one adjective, the class marker follows the final adjective, as represented in (9)-(10).

\begin{tabular}{|c|c|c|c|c|c|}
\hline \multirow[t]{2}{*}{ (9) } & (a) & $\begin{array}{l}\text { túbéré } \\
\text { shoe }\end{array}$ & $\begin{array}{l}\text { wó } \\
\text { black }\end{array}$ & $\begin{array}{l}\text { č̀ } \\
\text { pretty }\end{array}$ & $\begin{array}{l}\text { vớ=?̄ } \\
\text { new }=\text { CL2 }\end{array}$ \\
\hline & (b) & $\begin{array}{l}\text { ‘a pretty } \\
\text { túbéré } \\
\text { shoe } \\
\text { ‘a PRETT }\end{array}$ & $\begin{array}{l}\text { new bla } \\
\text { č̀ } \\
\text { pretty } \\
\text { new bl }\end{array}$ & $\begin{array}{c}\text { k shoe' } \\
\text { wó } \\
\text { black } \\
\text { ck shoe }\end{array}$ & 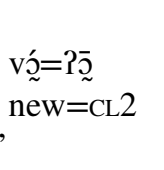 \\
\hline \multirow[t]{2}{*}{ (10) } & (a) & $\begin{array}{l}\text { túbéré } \\
\text { shoe } \\
\text { 'a pret }\end{array}$ & $\begin{array}{l}\text { vó } \\
\text { new } \\
\text { NEW bl }\end{array}$ & $\begin{array}{l}\text { wó } \\
\text { black } \\
\text { ack shoe }\end{array}$ & $\begin{array}{l}\mathrm{c \grave {c }}=\mathrm{g} \grave{\tilde{\varepsilon}} \\
\text { pretty=CL2 }\end{array}$ \\
\hline & (b) & $\begin{array}{l}\text { túbéré } \\
\text { shoe } \\
\text { 'a pret }\end{array}$ & $\begin{array}{l}\text { vó } \\
\text { new } \\
\text { NEW b }\end{array}$ & $\begin{array}{l}\text { cÉ } \\
\text { pretty } \\
\text { ack shoe }\end{array}$ & $\begin{array}{l}\text { wó }=? \overline{\check{\sim}} \\
\text { black=CL2 }\end{array}$ \\
\hline
\end{tabular}

The free ordering supports our idea that what are traditionally analyzed as nominal suffixes are in fact clitics attached at the end of the noun phrase. This treatment makes it unnecessary to stipulate the existence of complex patterns of adjective incorporation or noun-adjective compounding, for which we find no evidence in Kafire. 
Compounding is commonly assumed in descriptions of various Gur languages as an explanation for the post-adjectival position of the noun class marker (Carlson 1994: 164; Dombrowsky-Hahn 2015: 228; Creissels 2018: 733-736, inter alia). It is also assumed, based on phonological evidence, in the study of another Senufo language, Tagbana, in Traoré 2020; see also Rialland et al. 2021. We believe that the phonological evidence is compatible with the analysis of noun class markers as clitics, if they are viewed as belonging to the same phonological word as their host. Syntactic evidence for compounding is based on the detached position of the noun class markers, which we believe follows more naturally if they are analyzed as clitics, for the following reasons.

First, the number of adjectives following the head noun does not seem to be restricted, contrary to what is expected of typical compounds. The order of the adjectives is, moreover, flexible (see again the examples in (9)-(10)), and changes of order produce little semantic effect. Second, the construction shows no semantic effects typical of compounding or incorporation in other languages, and the nounadjective combinations show no evidence of lexicalization. Finally, there is no alternative in Kafire to placing the noun class marker after the last adjective. The compounding analysis would lead us to assume, rather unusually, that Kafire simply lacks an alternative to compounding, or that it lacks altogether an adjectival modification construction that does not involve compounding. The clitic analysis does not require us to make such an exotic assumption.

The structure in (11) shows our analysis of the example in (9a). We assume that multiple adjectives (AP) can freely modify a noun phrase (NP); in this particular example, there happen to be three of them. The class marker is a determiner (D) that attaches at the end of the noun phrase, turning it into a full-fledged, class-marked noun phrase ready for use in discourse (DP). (Unlike in English, we find no evidence in Kafire for a separate specifier position, hence we assume that $\mathrm{D}^{\prime}$ coincides with DP; this assumption is, however, in no way crucial to our account.)

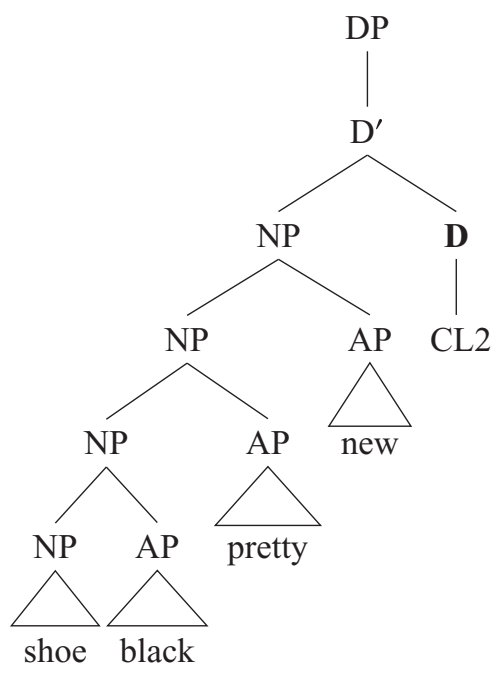


To summarize, we suggest that noun class markers function as determiners that attach to the noun phrase and turn it into a DP. The markers' obligatoriness explains why they have been mistaken for nominal suffixes in previous studies. In the next subsection we further illustrate this analysis and discuss an important irregularity in the appearance of class markers with certain nouns.

\subsection{Some nouns have inherent determiners}

A number of nouns do not take an overt indefinite marker, yet such a marker appears when the noun is definite or when it is modified by an adjective. Nouns that are characterized by such behavior are rather diverse in form and meaning, cf. pà

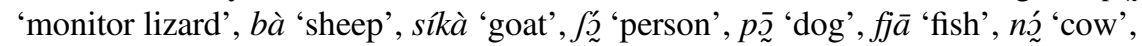
pìcá 'lady', càrà 'lion', tésó ‘toad', sèsś 'panther', màzà 'peanut', kóró 'canoe', kàji 'war'. They also include recent borrowings (which typically come from Jula, a Mande language without noun classes, and more rarely from French), cf. nè?èsó 'bike' or màrfá 'gun' (from Jula).

In (12a), the noun $p a \grave{a}$ 'monitor lizard' appears without an overt determiner when used in a non-specific indefinite reading; (12b) shows that it combines with a definite determiner in a regular way. (We leave aside here the question of the exact meaning of the indefinite determiner, which appears in non-referential, indefinite specific, as well as definite non-specific contexts.)

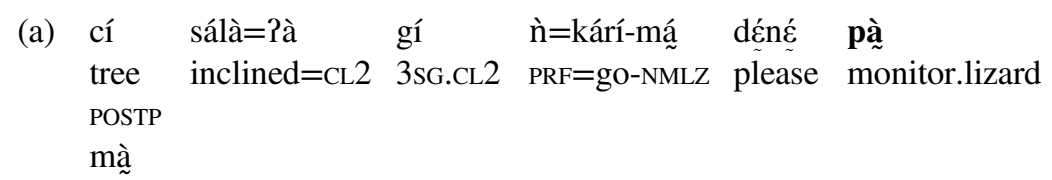

'An inclined tree, it is easy to go (slither) on [it] for a monitor lizard.' (2020_Kaf_Riddles_Nibontinnin_01_031)

(b) pà̀=w gá lúgú

monitor.lizard=CL1.DEF COND climb

'And when the monitor lizard climbs...'

(2020_Kaf_Riddles_Nibontinnin_01_036)

To account for this behavior of a restricted set of nouns, we use what is known in Lexical-Functional Grammar as the mechanism of LEXICAL SHARING (Wescoat 2002, 2005, 2007). Lexical sharing describes situations where a single word can "fill in" multiple slots in the phrase structure, for example, where a pronoun is fused with an auxiliary and behaves as a single word yet instantiates both a subject and an auxiliary in the syntactic structure (cf. English he's or I'll, which behave in many respects as single words but correspond simultaneously to a subject and an auxiliary in the syntax).

The structures in (13a)-(13b) illustrate the way lexical sharing can be used to account for cases of preposition-determiner contraction in French, where, again, a single preposition can be assumed to instantiate two different syntactic nodes in the 
structure. This analysis follows Wescoat 2007, but we omit here the discussion of technical details (see Dalrymple et al. 2019: 114-116, also Bresnan 1997, Nikitina 2008 for a related notion of head sharing). In (13a), the preposition and the feminine determiner are separate words, but in (13b), the preposition and the masculine determiner are realized together as a single word.

(13) (a)

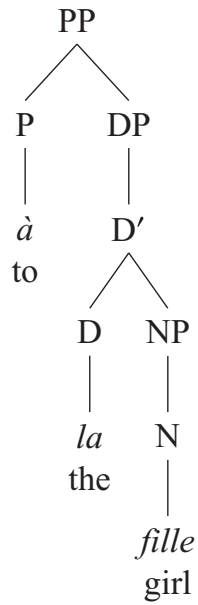

(b)

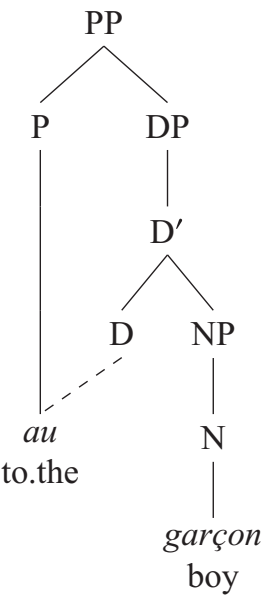

We believe that the irregular nouns of Kafire are another example of the same phenomenon: they are associated with more than one terminal node in the phrase structure, and project a noun along with its indefinite determiner. In (14b), for example, a single word is lexically associated with information that is normally distributed across two different words, a noun and a determiner (cf. (14a)). Simply put, the noun 'monitor lizard' is "shared" by two syntactic nodes in the structure, projecting a class-marked DP rather than a simple NP.

(14) (a)

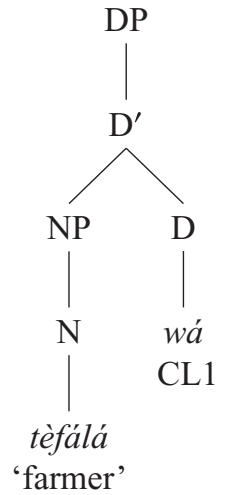

(b)

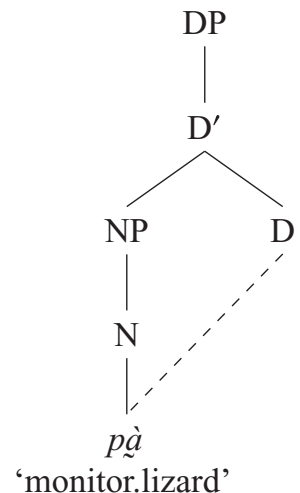


Lexical sharing is only possible when the two syntactic nodes projected by the word are adjacent in the phrase structure. This explains why the determiner is only absent in Kafire when an irregular noun appears at the right edge of the noun phrase. When the same noun is modified by an adjective, and lexical sharing is not possible, the adjective must be followed by an overt determiner, as in (16b). The difference between (16a) and (16b) shows that a restricted set of Kafire nouns are ambiguous: they can behave syntactically as a simple noun or as a combination of a noun and an indefinite determiner.
(a) mì mà̀à krú
1sG peanut chew
'I chewed peanuts.'
(b) mì mà̀à pēewè krú
1SG peanut braised $=$ CL1 chew
'I chewed braised peanuts.'

(16) (a)

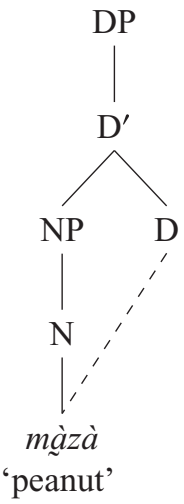

(b)

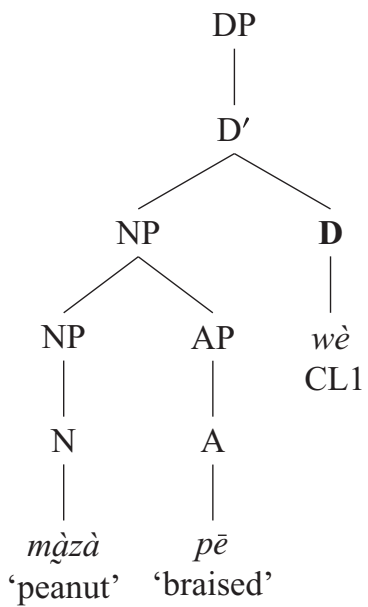

\subsection{Demonstratives and the DP}

The last aspect of the noun phrase structure that needs clarifying concerns the position of demonstratives. As we show in this section, the syntactic behavior of demonstratives differs from that of noun class markers, so we treat them as a separate category (Dem). Demonstratives appear in a position external to the noun class marker, and unlike the noun class marker, they can appear before or after the noun phrase. 
(17) (a)

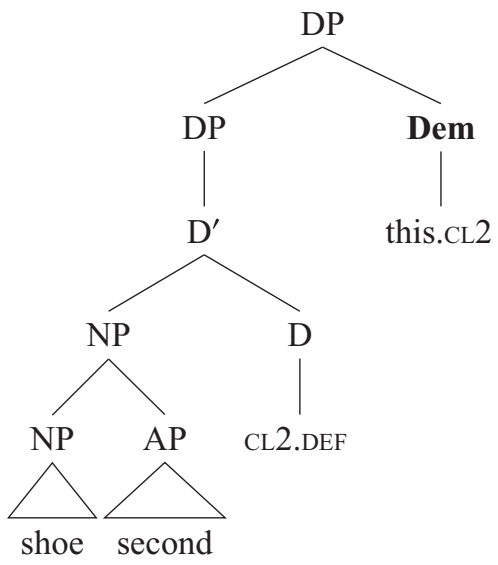

(b)

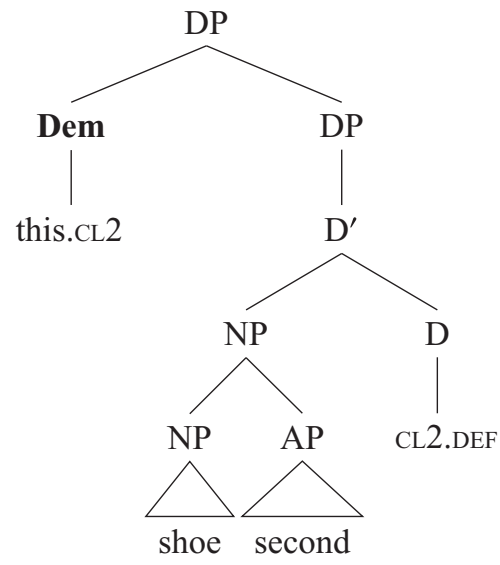

The ordering difference corresponds to a difference in discourse status, which we cannot explore here in detail. Crucially, in both cases the demonstrative agrees with the class-marked noun phrase (DP) rather than with the head noun. As we saw in (5), when the noun is modified by a class-assigning adjective, the demonstrative - like the determiner - fails to agree with the head noun (18b). 
(18)

(a)

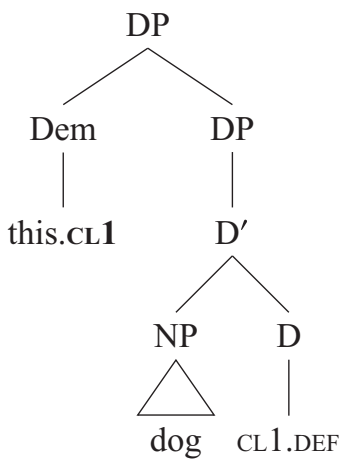

(b)

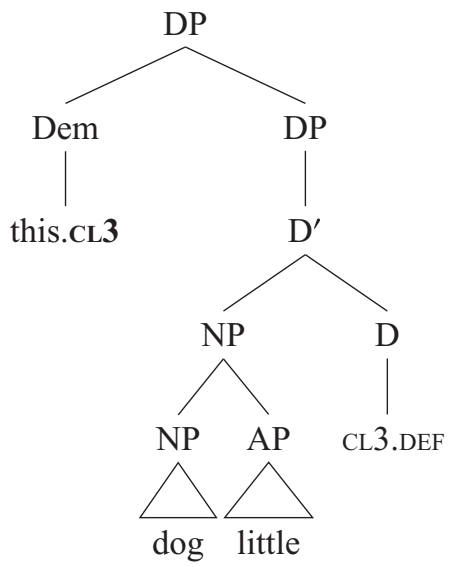

The demonstratives' adjunct position in our structure corresponds well with coordination facts. In Kafire, only class-marked noun phrases (DPs but not NPs) can be coordinated. Class markers cannot scope over two coordinated NPs, but must be attached to each one of them (19).
(a) $\mathrm{p} \bar{\sim}=\mathbf{w}$
ní sìtúgú $=\mathbf{w}$
$\operatorname{dog}=\mathbf{C L} 1$.DEF and $\quad$ Cat $=$ CL1.DEF
(b) *pD̄ ní sìtúgú=w
dog and cat=CL1.DEF
'the dog and the cat'

Several adjectives can modify the same noun, but they cannot be coordinated (20a)(20b). The noun that the adjective modifies cannot be omitted even when it is the same for the two coordinated noun phrases (21a)-(21b).

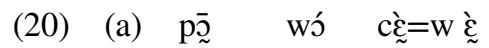 dog black pretty $=$ CL1
'a pretty black dog'




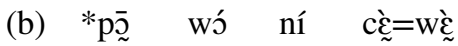
dog black and pretty $=$ CL1 'a black and pretty dog'

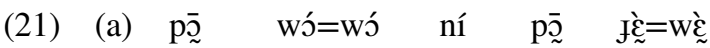

$\operatorname{dog}$ black $=$ CL1 and $\operatorname{dog}$ pretty $=$ CL1

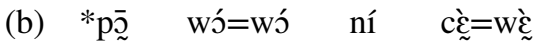
$\operatorname{dog}$ black $=$ CL1 and pretty $=$ CL1 'a black dog and a pretty dog'

In contrast, when two class-marked noun phrases are coordinated, a demonstrative can be shared by them (each of the coordinates can also have their own demonstrative, but we are interested here in cases where the demonstrative scopes over the coordination, because they provide evidence for the demonstrative's structural position with respect to the class marker). In (22a)-(22b), the demonstrative scopes over the two class-marked noun phrases, suggesting that it adjoins at a level above the class marker, both when it appears after the noun phrase and when it appears before it, as in (23a)-(23b).
(a) wè
$[\mathrm{p} \overline{\mathrm{y}}=\mathrm{w}$
ni sètúgú $=$ w]
this.CL1 dog=CL1.DEF and cat=CL1.DEF
'this dog and cat'
(b) $[\mathrm{p} \bar{\sim}=\mathrm{w} \quad$ ní sètúgú $=\mathbf{w}]$ wè
$\operatorname{dog}=\mathrm{CL} 1 . \mathrm{DEF}$ and $\mathrm{cat}=\mathrm{CL} 1 . \mathrm{DEF}$ this.CL1
'this dog and cat'

(23) (a)

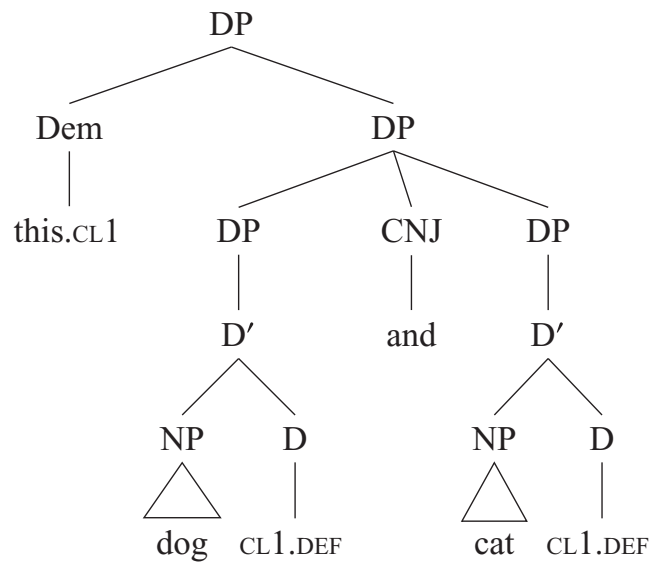


(b)

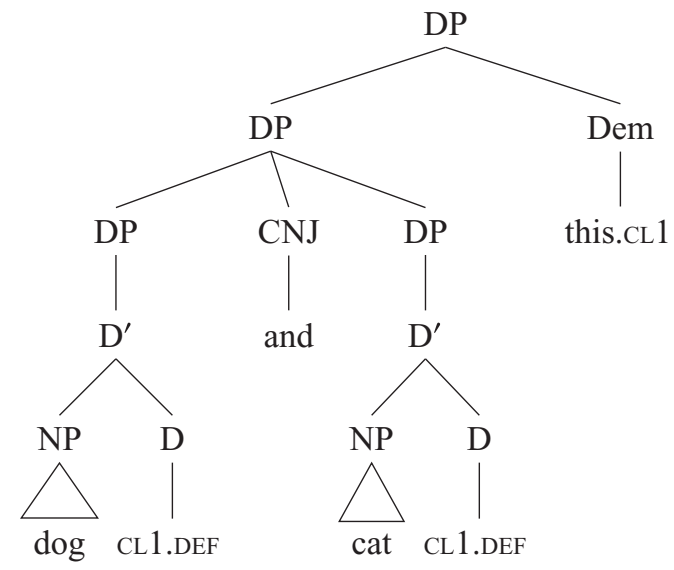

Note that the demonstrative agrees with the coordinate DPs in number, i.e. it appears in the singular when both coordinates are singular, even though semantically, the coordinate structure refers to more than one entity. This effect is formalized for English (cf. 'this boy and girl') in King \& Dalrymple 2004, and we assume that the same account would hold for Kafire. We set the technical details aside until further study (along with the issue of the demonstrative's agreement in class with non-matching coordinates, see Sadler 2003).

\section{Agreement in class: A Lexical-Functional Grammar formalization}

\subsection{Noun class specification on nouns versus adjectives}

One of the crucial observations in this study is the difference between two classes of adjectives with respect to agreement properties. Most adjectives have no effect on the agreement between the determiner and the head noun. Several adjectives, however, impose their own class on the noun phrase that they modify, and that specification overrules the class of the head noun at levels external to the NP.

To account for the behavior of class-assigning adjectives we suggest that the role of noun class information depends on the way that information is encoded in individual lexical entries. On nouns, class specification is optional, so it can be overruled by the value contributed by an adjective (or by semantically motivated class markers, as we discuss in the next subsection). On most adjectives, noun class specification is absent, hence their presence has no effect on agreement. Some adjectives have an inherent class, and their class value can be passed on to the noun phrase.

We now turn to formalizing the intuition about these lexical differences using the tools of Lexical-Functional Grammar (LFG). Because of the surface-oriented nature of the framework, the account does not make reference to a distinction 
between overt and covert agreement features or directionality of agreement (Haug \& Nikitina 2016). Because of the framework's lexicalist nature, differences between nouns and the two types of adjectives can be stated directly on lexical items. We list the class information as an optional value on nouns, as an obligatory value on some adjectives, and as an absence of value on others. The partial LFGstyle lexical entries below assign this information to a noun (24), a class-assigning adjective (25) and a regular adjective (26).

Arrows are used in the LFG notation to represent the way that information is shared by nodes in the phrase structure; we explain it in more detail after we introduce the lexical entries. The relevant information in our lexical entries consists of the word's lexical meaning (represented as the value of the feature PRED) and class specification (represented as the value of the feature CL). The technical details of the notation are not relevant for our analysis, the crucial point being that individual nouns and adjectives can contribute, in addition to their lexical meaning, a cLASs feature which can be passed on along the syntactic tree to the noun phrase in which they appear.

The optionality of noun class specification on the noun $p \bar{\sim}$ ' 'dog' is stated directly in (24) (the specification is in parentheses). Noun class specification is absent on the regular adjective wó 'black' in (25), so the presence of that adjective has no effect on the class of the noun phrase. The class value associated with the adjective $b \bar{\imath}$ 'little' is stated in (26) through what is known in LFG as INSIDE-OUT FUNCTION APPLICATION, which defines constraints on enclosing structures. In our case, the specification on $b \bar{\imath}$ 'little' attributes a class value (Class 3 ) to the element of which the adjective is an adjunct (the noun phrase). Simply put, the adjective in (26) can only modify noun phrases of Class 3.

(24) Optional specification of class value on nouns:

$\begin{array}{ll}p \bar{\sim} \quad \mathrm{N} \quad(\uparrow \mathrm{PRED})={ }^{\prime}{ }^{\mathrm{DOG}}{ }^{\prime} \\ & ((\uparrow \mathrm{CL})=\mathbf{1})\end{array}$

(25) Absence of class specification on regular adjectives: wó Adj ( $\quad$ PRED $)=$ 'BLACK'

(26) Class-assigning adjectives can only modify noun phrases with a particular class value:

$b \bar{\imath} \quad$ Adj $\quad(\uparrow$ PRED $)=$ 'LITTLE'

$((\mathrm{ADJ} \in \uparrow) \mathrm{CL})=\mathbf{3}$

In Lexical-Functional Grammar, information from lexical items is propagated up the syntactic tree and unified at an interpretive level known as F-STRUCTURE, or functional structure. It is at that level that information coming from different parts of the construction is checked for consistency, so that structures with conflicting or missing information can be ruled out as ill-formed. In the case of adjectival modification, both the head noun and its modifiers may contribute a class value to the f-structure associated with the NP. If the values are different, the obligatory value coming from the adjective will override the optional value coming from the nominal head. 
In the partial structure below, the distribution of lexical information between the elements of the interpretive f-structure is defined by functional annotations on phrase structure nodes: $\uparrow=\downarrow$ indicates sharing of all information (the node is equivalent in its specification to its mother node), and $\downarrow \in$ ( $\uparrow$ ADJ) specifies that the daughter node contributes information to the mother node's substructure (the adjunct). The resulting partial f-structure unifies noun class information coming from the two sources and resolves the potential conflict in favor of the obligatory value (here, Class 3).

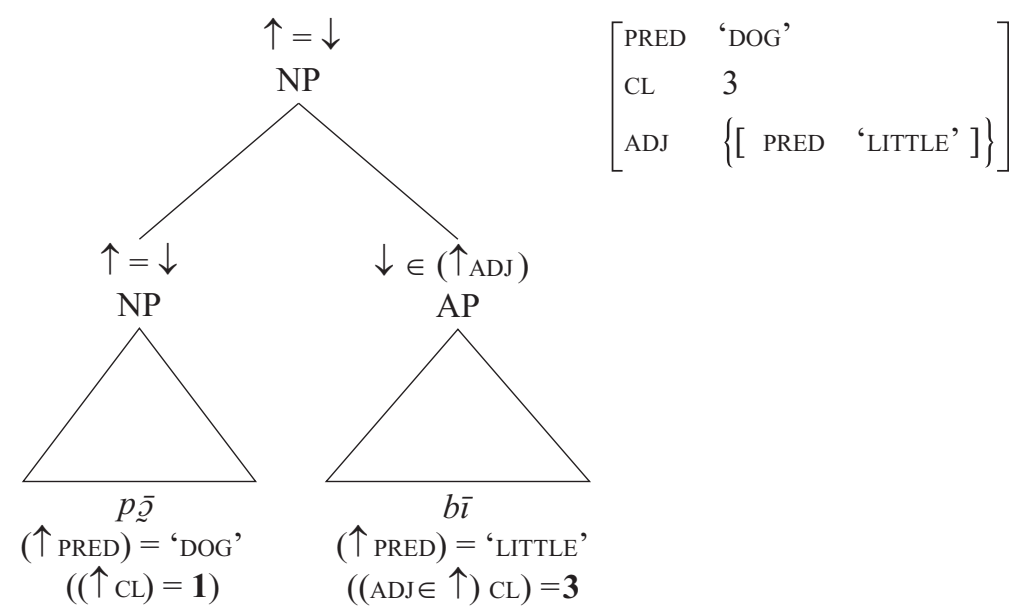

Our lexical specification in (26) explains why different class-specifying adjectives can only be used together if they bear the same class value. While adjectives not carrying class information combine freely with other adjectives, adjectives that are inherently specified for class do not normally go well together, unless they are specified for the same class. To sum up, we suggest that both nouns and adjectives can contribute class information to the noun phrase, with which the choice of determiners, demonstratives and anaphoric pronouns must be consistent. Most adjectives are not associated with a particular class, and their presence is irrelevant to agreement. Several adjectives are associated with a particular class, and their presence defines the class of the noun phrase in which they appear; that class might differ from the one normally associated with the head noun. Nouns are associated with specific classes, but their class specification is optional and can be overridden by that of the adjective when the two are in conflict.

We now turn to the last technical component of our analysis: the modeling of agreement with determiners. We need to make sure that the determiner agrees in class with the noun phrase, and in particular, that it must agree with the head noun in the absence of class-assigning adjectives. That is not trivial because we have so far relied on optional specification of class on nouns, making it possible for the NP not 
to inherit its class value from the head noun. We now need to make sure that this flexibility is only exploited in cases of potential conflict with a class-assigning adjective, and that it does not get abused when the adjectives are not there.

Constraining combinations of nouns with determiners is a challenge for accounts that do not associate nouns with a particular class (such as the Distributive Morphology account suggested in Traoré 2020). In Kafire, nouns show a certain degree of flexibility in the way they combine with class markers, but this flexibility is restricted to combinations with class-assigning adjectives and cases where the class marker contributes its own meaning (such as diminutivity or augmentativity). Apart from these, the choice of the noun class marker is restricted to just one class. Each noun is associated with a particular class, and that class cannot be predicted based on the noun's meaning (for example, $p \bar{\sim}$ ' 'dog' is Class 1 , but dè $1 \grave{\varepsilon}$ 'hyena' is Class 2; ná 'scorpion' is Class 1, but wòb 'snake' is Class 2; nã 'man' is Class 1, but

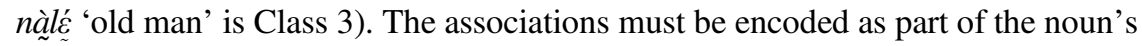
lexical entry, even though they can, in certain contexts, be overruled; they are encoded in our model by optional specifications of class on each noun in Kafire.

We define agreement of determiners by what is known in Lexical-Functional Grammar as a CONSTRAINING EQUATION (Kaplan \& Bresnan 1982). It is a type of constraint that forces a determiner to agree with any value that is already present in the structure, but prevents it from contributing a new value of its own. By adding a constraining equation to the lexical entry of each determiner we ensure that in order for the determiner to be used, the controller NP must bear a specific class value. The value may come from different sources, an adjective or a noun, but it may not be contributed by the determiner alone. Hence, in the absence of a class-specifying adjective, the determiner must agree with the class value inherited by the NP from its head noun, despite the optionality of that noun's class feature.

The structure in (28) shows how the different agreement mechanisms work together to capture the facts of Kafire agreement. The structure corresponds to the expression 'this little black dog', where the head noun is modified by two adjectives. The functional information on the nodes in the structure specifies how the information from the lexical items is integrated into one interpretive f-structure. The demonstrative, the determiner, and the head noun all contribute information to the same f-structure (as indicated by the $(\uparrow=\downarrow)$ notation), while the adjectives contribute information about the noun's adjuncts (as indicated by the $\downarrow \in(\uparrow$ ADJ) notation in the phrase structure).

The feature structure below the constituent structure illustrates how the class information is unified at the interpretive level of syntactic representation (the f-structure).

One of the adjectives ('black') contributes no class information, hence its presence is irrelevant for agreement. The other adjective ('little') specifies, through an inside-out function application, the class value of its superstructure, i.e. the class value of the noun phrase within which it appears. Since the class value on the head noun is optional, it is the value contributed by the adjective that gets inherited by the 
NP and that defines the agreeing value on the determiner. The demonstrative's value must in turn match the value of the DP it modifies.

(28) 'this little black dog'

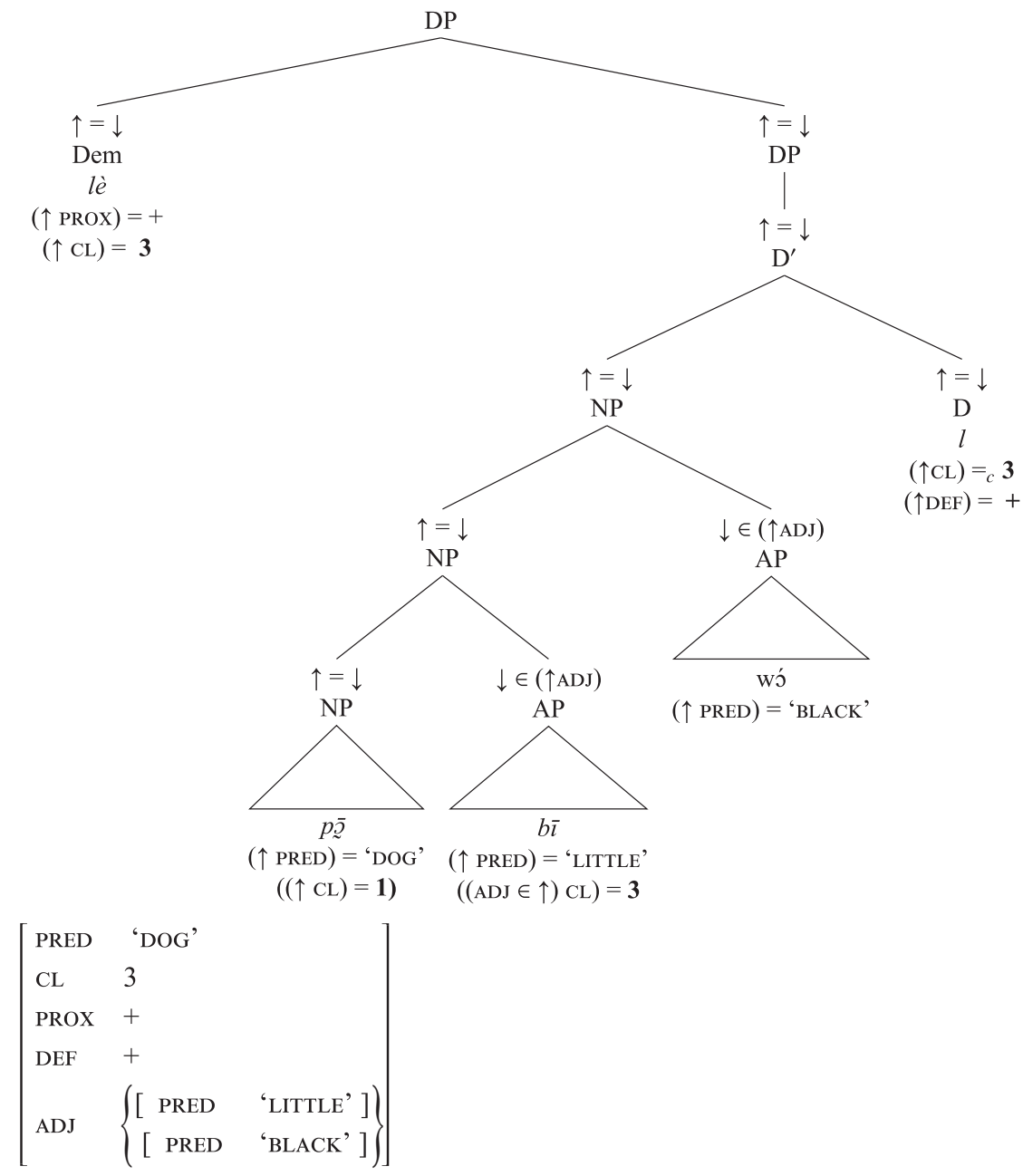

\subsection{Noun class markers have optional semantic content}

We will now turn to the other phenomenon that justifies making the class information optional on nouns: the semantically motivated use of class markers, or the ability of class markers to override the class specification on the corresponding noun phrase in cases where they contribute their own semantic content. 
Cross-linguistically, formal agreement classes develop from systems of semantically motivated genders or classifiers (Nicole 1999; Aikhenvald 2000, inter alia). Some of the noun class markers in Kafire still retain traces of their original lexical meaning. This is manifested, most importantly, in a certain degree of flexibility in class assignment. Classes 2 and 3, for example, are associated with the augmentative and the diminutive meanings; they can attach to nouns of other classes, contributing the respective meanings, as in (29)-(30).

(29) gàsá= =à̀ 'a tooth' (tooth=CL1) gàsá =gà 'a big tooth' (tooth=CL2)

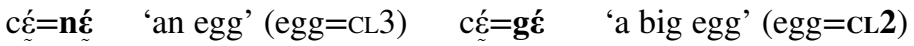

(30) cí=gē 'a tree' (tree=CL2) cí=lé 'a little tree' (tree= $=\mathbf{C L 3})$ síkà 'a goat' (goat.cL1) síká=là 'a little goat' (goat=CL3)

Class 4 markers can be used to derive mass nouns from certain count nouns: they contribute the meaning of unbounded quantity, as in (31).

$$
\begin{aligned}
& \text { cí=gē 'a tree' (tree }=\text { cL2) cí=rēe '(a quantity of) trees' (tree }=\mathbf{c L 4} \text { ) } \\
& \text { pjā }=\mathbf{l a} \text { 'a seed' (seed=cL3) pjā=rā '(a quantity of) seeds' (seed=CL4) }
\end{aligned}
$$

Class 5 markers can be used to refer to abstract qualities associated with categories of humans (32).

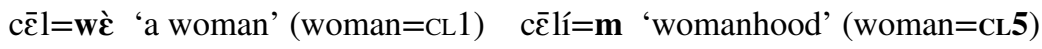

$$
\begin{aligned}
& \text { nà̀=wà 'a man' (man=CL1) nà̀=m 'manhood' (man=CL5) }
\end{aligned}
$$

The semantic values associated with noun class markers are summarized in Table 6. Note that the augmentative and the diminutive overlap in one aspect of their meaning: both Class 2 and Class 3 markers can be used to encode pejorativity.

To account for the non-agreeing uses, we assume that determiners of Classes 2-5 are not only associated with a formal agreement value but can alternatively contribute semantic values: AUGMENT (Class 2), DIMIN (Class 3), MASs (Class 4) and ABSTR (Class 5). The determiners can either be licensed by a controller noun phrase of the appropriate class or, in cases of a mismatching noun phrase, contribute a semantic value, along with its associated class value. This pattern accords well with the general tendency described by Wechsler (2011: 1009) as the Agreement Marking Principle:

Agreement is driven by a syntactic feature of the controller if the controller has such a feature. If the controller lacks such a feature, then the target agreement inflection is semantically interpreted as characterizing the controller denotation.

We associate the markers of Classes 2-5 with the lexical entries in (33). As previously described, the vowel of the clitic depends on definiteness and, in the case 
of indefinite markers, on the preceding vowel. Only the semantically motivated use is compatible with noun phrases of a non-matching class.

$$
\begin{array}{llll}
\begin{array}{lll}
\text { Marker Category } \\
l \mathrm{~V}
\end{array} & \mathrm{D} & \begin{array}{l}
\text { Meaning 1 } \\
(\uparrow \mathrm{CL})={ }_{\mathrm{c}} 2
\end{array} & \begin{array}{l}
\text { Meaning } 2 \\
(\uparrow \mathrm{AUGMENT})=+ \\
(\uparrow \mathrm{CL})=2
\end{array} \\
g \mathrm{~V} & \mathrm{D} & (\uparrow \mathrm{CL})=_{\mathrm{c}} 3 & \begin{array}{l}
(\uparrow \mathrm{DIMIN})=+ \\
(\uparrow \mathrm{CL})=3
\end{array} \\
r \mathrm{~V} & \mathrm{D} & (\uparrow \mathrm{CL})={ }_{\mathrm{c}} 4 & \begin{array}{l}
(\uparrow \mathrm{MASS})=+ \\
(\uparrow \mathrm{CL})=4
\end{array} \\
m \mathrm{~V} & \mathrm{D} & (\uparrow \mathrm{CL})={ }_{\mathrm{c}} 5 & \begin{array}{l}
(\uparrow \mathrm{ABSTR})=+ \\
(\uparrow \mathrm{CL})=5
\end{array}
\end{array}
$$

Table 7 and the specifications in (33) only list the interpretations associated with regular productive uses. Certain nouns can also appear with different determiners depending on their interpretation, but such uses are highly lexicalized and are best treated as instances of ambiguity in the noun's meaning; for example, the same nouns are used as Class 1 to refer to ethnicity but as Class 4 to refer to the corresponding language (cf. similarity to pairs such as un français (human)-le français (language)). This is different from the way the markers for Classes 2-5 combine with the same count noun to derive the regular interpretations listed in Table 7; the regularity suggests that the interpretations are indeed associated with individual determiners.

The structures in (35) illustrate the contrast between agreeing and non-agreeing determiner uses. The non-agreeing use produces a semantic effect. Note that the flexibility in class assignment is only possible due to the optionality of the class value in the lexical specification on nouns. The agreeing use is described by a constraining equation, i.e. it presupposes that the determiner combines with an NP with a specific class value. The non-agreeing use, however, is described by a regular equation, predicting that the head noun's class information can be overruled by the class value contributed by the determiner, which functions in this case as a diminutive, augmentative or an unbounded quantity marker.

\begin{tabular}{ll}
\hline Class 2 & bigness; pejorativity; other augmentative values \\
Class 3 & smallness; pejorativity; other diminutive values \\
Class 4 & terms for unbounded quantities of objects \\
Class 5 & abstract qualities \\
\hline
\end{tabular}


(34) cí=gē 'a tree'

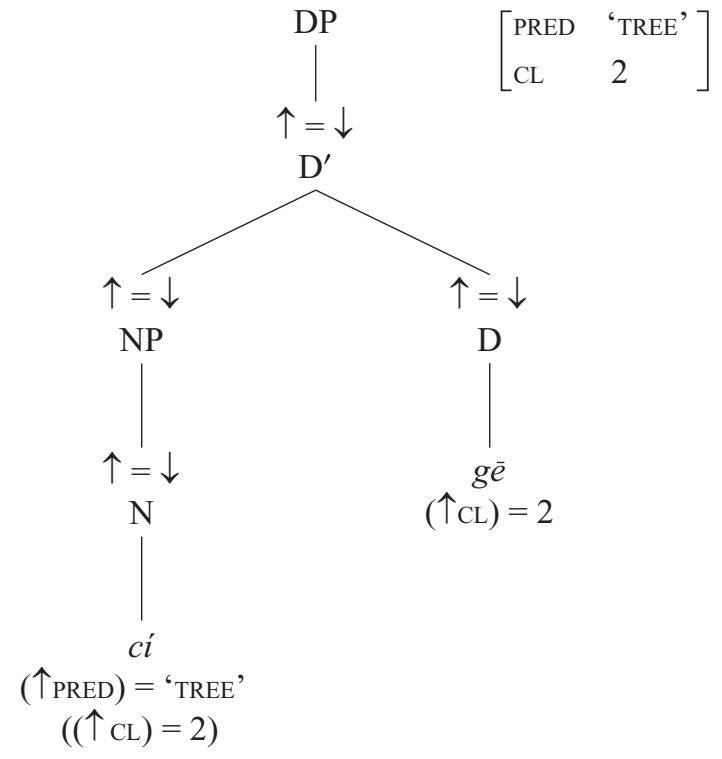

(35) cí=lé 'a little tree'

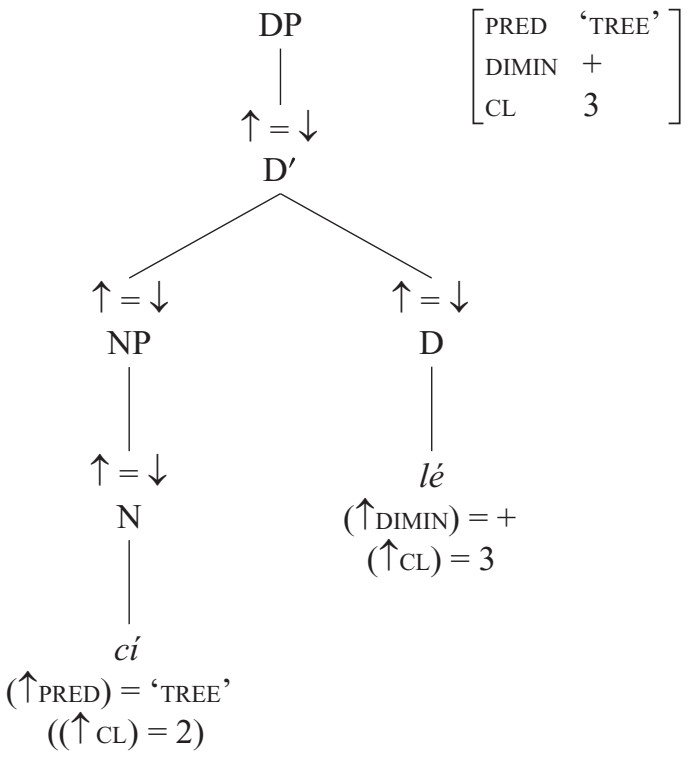


Our treatment differs from the treatment adopted in Traoré 2020 for Tagbana, where class markers are assigned additional derivational functions, such as a diminutivizing or a nominalizing function. Our account allows individual class markers to contribute additional meanings, but it does not treat such combinations as new words. The difference between the two accounts can be illustrated by the way they treat nominalization. According to Traoré 2020, class markers can be used in Tagbana to derive nouns from verbs. In our account, nouns in Kafire are zeroderived from verbs and are consistently associated with Class 5 in an action nominalization reading. While the two solutions cover the same set of data, the use of Class 5 markers with action nominalizations is motivated in our account by a historical association of that class with abstract meanings (many abstract nouns referring to processes and states, such as jáa 'illness', nún̄̄ 'sleep' or 'knowledge', are of Class 5 in Kafire, even though they are not derived from verbs).

Our account correctly predicts the way action nominalizations combine with adjectives. In (36), the zero-derived nominalization is modified by an adjective, and the noun phrase is marked as Class 5 because that is the class associated with action nominalizations. If the class marker is assumed to be a derivational suffix it becomes difficult to explain why it attaches to the adjective rather than the verb root. The verb and the adjective would have to be analyzed as a compound, from which a nominalization is derived; this solution seems unmotivated to us, at least in the case of Kafire.

$$
\begin{aligned}
& \mathrm{m} \bar{\sim} \mathrm{j} \overline{\mathrm{j}} \quad \mathrm{J} \overline{\mathcal{\varepsilon}}=\mathrm{m} \\
& 2 \mathrm{sG} \text { dance pretty=CL5.DEF } \\
& \text { 'your beautiful dancing' }
\end{aligned}
$$

As we already mentioned, our account does not preclude polysemy, i.e. it allows the same noun to be associated with different class markers with different meanings. Some of the zero-derived deverbal nouns can have readings other than that of action nominalization. Such readings are associated with Class 4, but they are highly lexicalized and irregular: they are not available with every verb and they cannot be predicted based on the verb's meaning (cf. sóPó 'cook' - só? $\bar{y}=r$ 'the kitchen' vs. túgó 'load' - túg $\bar{o}=r$ 'the load' vs. $k \bar{a}$ 'chew' $-k \bar{a}=r$ 'the meat'). We treat such meanings as a matter of irregular polysemy of the relevant deverbal noun, which has a productive meaning of action nominalization (systematically associated with Class 5) but may also have additional, idiosyncratic meanings (associated, for historical reasons, with Class 4, but not necessarily motivated at the synchronic level).

\subsection{Discourse factors in DP-external agreement}

Up to now we have focused on the way agreement works at the level below the DP. We conclude with an overview of agreement with anaphoric pronouns. 
Pronouns agree in class with their antecedent. Such agreement is regular in all but one respect. Older generations of proficient speakers exhibit a pattern of semantic agreement that is not attested with younger speakers or outside narrative genres (cf. the discussion of morphosyntactic differences between proficient narrative performances and everyday discourse in Nikitina 2018, based on data from another language spoken in Côte d'Ivoire). Narrative agreement concerns nouns that refer to characters in traditional stories. Instead of agreeing according to the value normally associated with the noun (and manifested in the choice of a determiner), anaphoric pronouns refer to such characters in Class 1, i.e. the class historically associated with humans.

This pattern of narrative agreement is illustrated in a pair of sentences extracted from a text in our corpus (37)-(38). In (37), 'hyena' combines with a Class 2 determiner, as expected, but a Class 1 emphatic pronoun is used to refer to Hyena (the emphatic pronoun is used here in a logophoric function, to signal reference to the reported speaker; Silué In prep.a). In (38), a Class 1 anaphoric pronoun is used again to refer to Hyena as a character in the story.

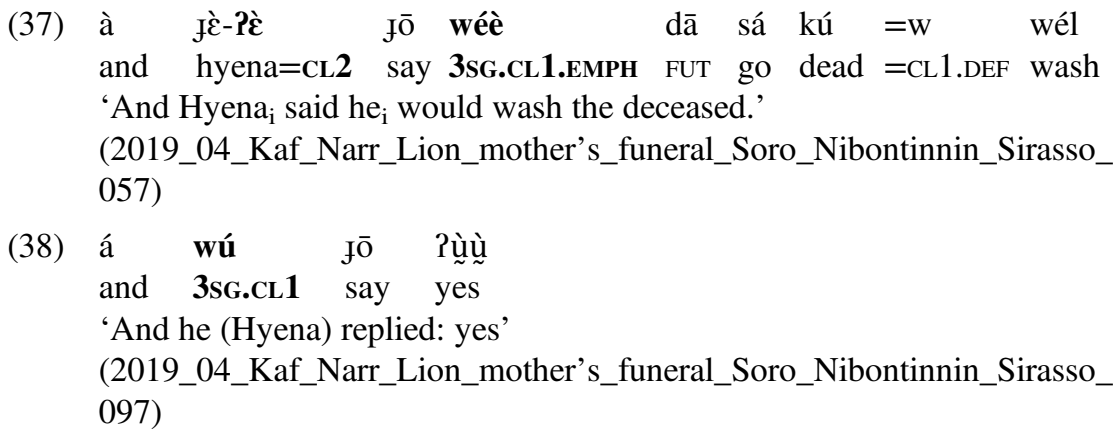

The phenomenon of narrative agreement is different from the semantically motivated use of determiners discussed in the previous subsection. In (37), the noun combines with its regular Class 2 marker, and the irregularity is only manifested in the choice of anaphoric pronoun. We explain this use as an instance of personification, characteristic of cases where a noun phrase refers to a character, naming a highly agentive, unique (in the context of a particular story) and humanlike participant.

Narrative agreement is only attested with highly volitional acting characters; in contexts where no volitionality is involved the same entity agrees in its regular class. In (39), from the same story, a Class 2 anaphoric pronoun is used to refer to Hyena, in a way consistent with the determiner choice. The absence of personification is explained by the fact that the pronoun refers to the character in a rather passive role: Hyena is treated here as an object rather than a volitional agent. Such examples suggest that narrative uses of Class 1 anaphors are licensed by situational animacy, i.e. they are highly dependent on the discourse context. 


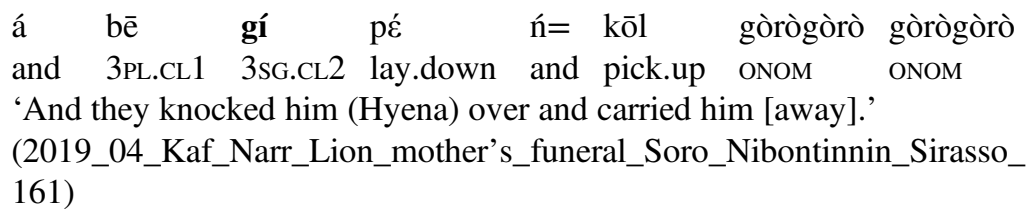

Unlike determiners and demonstratives, which agree based on the formal noun class value, anaphoric pronouns of Class 1 are sensitive to a mismatch between the formal value and the semantic content. They can be described as looking for a highly human antecedent, regardless of its noun class value.

We can capture the effect of personification by essentially the same method as the one we used to license semantically-motivated uses of determiners, but this time polysemy characterizes pronouns rather than determiners. We associate pronouns of Class 1 with two different lexical entries. One simply specifies that the antecedent is of Class 1; the other specifies that the antecedent is human. The latter lexical entry is only attested in older speakers who retain the archaic discourse-motivated use. We leave out the technical details but refer the reader to the literature on pronominal binding where restrictions on antecedents are modeled within the Lexical-Functional Grammar framework (Dalrymple 1993, Dalrymple et al. 2019).

\section{Conclusion}

The major aim of this study was to describe the system of noun class agreement in Kafire and outline a formal solution to a number of its challenging properties. The formal tools offered by the framework of Lexical-Functional Grammar helped us account for the complexity of that system. Although simple-looking at the surface, noun class agreement of Kafire turns out to involve an interplay of formal and semantic factors which presumably attests to the system's transitional status from semantically-motivated to formal agreement. The transitional status is manifested in the availability of non-agreeing determiner uses, archaic patterns of semantic pronominal agreement, and unusual behavior of certain adjectives. We believe that the same transitional status explains the lexical split within the class of adjectives: only some of the adjectives have an effect on the agreement properties of the entire noun phrase, including adjectives that are associated with the archaic meaning of certain noun classes (diminutivity in the case of $p \bar{\imath}$ 'little' or kpēle 'short'; augmentativity in the case of kpó 'big').

The multi-level lexicalist architecture of Lexical-Functional Grammar helps us account for the quirky behavior of class-assigning adjectives, as well as the dual function of determiners and the multiple sources of noun class information within the noun phrase. Our account reconciles the noun class markers' rigid syntax (they behave as obligatory determiners) with their semantic flexibility (they sometimes agree with the noun phrase and sometimes contribute their own value). 
The complexity of our data suggests that in Kafire, agreement in noun class is a heterogeneous phenomenon, comprising such different aspects as the optional and to some extent meaning-based 'agreement' of noun phrases with determiners, the rigid agreement of demonstratives, and (in older speakers) discourse-based anaphoric agreement with pronominal antecedents. Multiple formal tools developed within Lexical-Functional Grammar had to be used together to account for that heterogeneity.

At the descriptive level, our account has implications for the study of other Senufo languages, most importantly since it presents an alternative to the traditional treatment of noun class markers as nominal suffixes. Their treatment as clitics, we argued, responds better to the empirical reality of Kafire and helps avoid postulating exotic patterns of obligatory compounding.

\section{REFERENCES}

Aikhenvald, Alexandra Y. 2000. Classifiers: A typology of noun categorization devices. Oxford: Oxford University Press.

Baron, Bertille. 2016. The syntax of Nafara DP. PhD dissertation, Southern Illinois University at Carbondale.

Bond, Oliver, Greville G. Corbett, Marina Chumakina \& Dunstan Brown (eds.). 2016. Archi: Complexities of agreement in cross-theoretical perspective. Oxford: Oxford University Press.

Börjars, Kersti, Rachel Nordlinger \& Louisa Sadler. 2019. Lexical-Functional Grammar: An introduction. Cambridge: Cambridge University Press.

Bresnan, Joan. 1997. Mixed categories as head sharing constructions. In Miriam Butt \& Tracy Holloway King (eds.), Proceedings of the LFG97 Conference, 1-17. Stanford: CSLI Publications.

Bresnan, Joan, Ash Asudeh, Ida Toivonen \& Stephen Wechsler. 2015. Lexical-functional syntax. Chichester: Wiley Blackwell 2nd edn.

Carlson, Robert. 1994. A grammar of Supyire. Berlin: Mouton de Gruyter.

Creissels, Denis. 2018. Current issues in African morphosyntactic typology. In Tom Güldemann (ed.), The languages and linguistics of Africa., 712-821. Berlin: De Gruyter Mouton.

Dalrymple, Mary. 1993. The syntax of anaphoric binding. Stanford: CSLI Publications.

Dalrymple, Mary, John J. Lowe \& Louise Mycock. 2019. The Oxford reference guide to Lexical Functional Grammar. Oxford: Oxford University Press.

Dombrowsky-Hahn, Klaudia. 2015. A grammar of Syer (Western Karaboro, Senufo): Phonology, morphology, argument realization. Cologne: Rüdiger Köppe.

Falk, Yehuda N. 2001. Lexical-Functional Grammar: An introduction to parallel constraint-based syntax. Stanford: CSLI Publications.

Hammarström, Harald, Robert Forkel, Martin Haspelmath \& Sebastian Bank. 2021. Glottologdatabase 4.4. https://doi.org/10.5281/zenodo.4761960.

Haug, Dag Trygve Truslew \& Tatiana Nikitina. 2016. Feature sharing in agreement. Natural Language \& Linguistic Theory 34(3). 865-910.

Kaplan, Ronald M. \& Joan Bresnan. 1982. Lexical-Functional Grammar: A formal system for grammatical representation. In Joan Bresnan (ed.), The mental representation of grammatical relations, 173-281. Cambridge, MA: The MIT Press.

King, Tracy Holloway \& Mary Dalrymple. 2004. Determiner agreement and noun conjunction. Journal of Linguistics 40(1). 69-104.

Manessy, Gabriel. 1996a. La détermination nominale en sénoufo. Linguistique africaine 16. 53-68.

Manessy, Gabriel. 1996b. Observations sur la classification nominale en sénoufo. Afrika und Übersee 79(1). 21-35.

Miehe, Gudrun \& Kerstin Winkelmann, eds. 2007. Noun class systems in Gur languages. Vol. 1. Southwestern Gur languages (without Gurunsi). Cologne: Rüdiger Köppe.

Nicole, Jacques. 1999. Les classes nominales dans les langues voltä̈ques: esquisse d'un cadre de description. Lome: SIL Togo. 
Nikitina, Tatiana. 2008. The mixing of syntactic properties and language change: Stanford University dissertation.

Nikitina, Tatiana. 2018. When linguists and speakers do not agree: The endangered grammar of verbal art in West Africa. Journal of Linguistic Anthropology 28(2). 197-220.

Rialland, Annie, Yranahan Traoré \& Caroline Féry. 2021. Nominal tonology and spreading rules in Tagbana (Frò?ò dialect). Studies in African Linguistics 50(2). 167-195.

Sadler, Louisa. 2003. Coordination and asymmetric agreement in Welsh. In Miriam Butt \& Tracy Holloway King (eds.), Nominals: Inside and out, 85-118. Stanford: CSLI Publications.

Silué, Songfolo Lacina. 2017. Documentation lexicale et esquisse phonologique du kafire, parler sénoufo de Sirasso dans le département de Korhogo. Université Félix Houphouët-Boigny MA thesis.

Silué, Songfolo Lacina. Forthcoming. In prep.a. Le discours rapporté en kafire (langue sénoufo de Côte d'Ivoire): Une analyse fondée sur les genres narratifs traditionnels: INALCO dissertation.

Silué, Songfolo Lacina. Forthcoming. In prep.b. A narrative corpus of Kafire. In Tatiana Nikitina, Ekaterina Aplonova, Abbie Hantgan-Sonko, Izabela Jordanoska \& Elena Perekhvalskaya (eds.), The SpeechReporting Corpus: Discourse reporting in storytelling, Villejuif-Paris: CNRS.

Traoré, Yranahan. 2020. The morphology and phonology of the nominal domain in Tagbana. New York: Peter Lang.

Traoré, Yranahan \& Caroline Féry. 2018. Nominal classes and phonological agreement in Tagbana. In Ryan Bennett, Andrew Angeles, Adrian Brasoveanu, Dhyana Buckley, Nick Kalivoda, Shigeto Kawahara, Grant McGuire \& Jaye Padgett (eds.), Hana-bana: A Festschrift for Junko Ito and Armin Mester, UC Santa Cruz. https://escholarship.org/uc/item/09m654fp.

Wechsler, Stephen. 2011. Mixed agreement, the person feature, and the index/concord distinction. Natural Language \& Linguistic Theory 29(4). 999-1031.

Welmers, William E. 1950. Notes on two languages in the Senufo. Group I: Senadi. Journal of West African Languages 26(1). 126-146.

Wescoat, Michael T. 2002. On lexical sharing: Stanford University dissertation.

Wescoat, Michael T. 2005. English nonsyllabic auxiliary contractions: An analysis in LFG with lexical sharing. In Miriam Butt \& Tracy Holloway King (eds.), Proceedings of the LFG05 Conference, 468-486. Stanford: CSLI Publications.

Wescoat, Michael T. 2007. Preposition-determiner contractions: An analysis in Optimality-Theoretic Lexical-Functional Grammar with lexical sharing. In Miriam Butt \& Tracy Holloway King (eds.), Proceedings of the LFG07 Conference, 439-459. Stanford: CSLI Publications.

Yéo, Kanabein Oumar. 2012. Etude comparative de la morphologie nominale de six langues sénoufo: Université Félix Houphoët Boigny dissertation.

\section{Authors' addresses: (Nikitina)}

CNRS-LACITO, 7 rue Guy Môquet BP 894800 Villejuif, France tatiana.nikitina@cnrs.fr

(Silué)

INALCO, 2 rue de Lille, 75007 Paris, France

songfololacina@gmail.com 